\title{
Religion as heritage, religion as belief: shifting frontiers of secularism in Europe, the USA and Brazil.
}

David Lehmann

Keywords: secularism, neo-Pentecostalism, evangelicals, religious regulation, Europe, Brazil, USA .

\section{Introduction}

This article seeks to construct the basis for an answer to the question why, despite the evidence of a decline in religious observance throughout Europe and (even) in the $\mathrm{USA}^{1}$, religion is, perhaps increasingly, a source or a motive or maybe a pretext for social conflict and sharp political rhetoric. The question is often answered in terms of religious freedom construed as the complete separation of religion and the state, as in Hillary Clinton's astonishing claim, in her Introduction to the US State Department's 2011 'International Religious Freedom Report', that 'Religious freedom provides a cornerstone for every healthy society. It empowers faith-based service. It fosters tolerance and respect among different communities. And it allows nations that uphold it to become more stable, secure and prosperous.' This notion of separation is more difficult than might appear, because the omnipresent heritage of religion in the public sphere and cultural and national identity of Western countries (including Latin America) cannot simply be conjured out of existence, and also because of its accompanying normative baggage and its indissoluble link to an exemplary projection of the United States Constitution and the European Human Rights Convention as models. I therefore advocate an approach in terms of regimes of religion-state relations, or of religious regulation, with an emphasis on the stability and legitimacy of those arrangements, whatever their content. The article will draw on transformations in the religious field in Europe, the US and Brazil to challenge and

\footnotetext{
* The research on which this article is based was a network funded by the UK Arts and Humanities Research Council under its Religion and Society Programme entitled 'Secularism: A reappraisal of institutional arrangements for religious regulation', award reference AH/F007566/1. The network was coordinated by me with Humeira Iqtidar.
} 
recombine analytical assumptions about those regimes of regulation in order to lay a more realistic and less ethnocentric basis for its comparative study.

The growing influence of conversion-led movements and the legitimacy of 'religion as belief' as distinct from 'religion as heritage' has major implications for inherited arrangements governing regimes of religious regulation. The absence of hierarchical institutions able to act as 'interlocuteurs valables' authorized to speak on behalf of 'religion as a whole' leads to the near-impossibility of a broad consensual basis for a delimitation of the boundaries between religion and the state. At the same time, there is something like a lag-effect whereby the followers of new Christian movements and of predominantly immigrant-based religions invoke their entitlement to ancient exemptions, privileges and recognitions still accorded to hierarchical Christian institutions whose support is declining. The underlying once-prevalent and deeply Christian cultural assumption that religion is entitled to certain exemptions because it is reliant on a hierarchy of virtuosi who make great sacrifices on behalf of the world as a whole (Hervieu-Léger, 2001) is lost, yet the corresponding entitlements and exemptions are not. What we see instead are new forms of the politicization of religion, and the use of religious privilege to claim inherited exemptions and entitlements. This means that non-religious interests can take advantage of exemptions and privileges reserved for identifiable religious institutions to promote agendas such as multiculturalism, anti-racism, or, conversely, cultural and racial exclusiveness, in addition to campaigns of moral salvation focused on the politics of marriage, reproduction and the body. To these can be added New Age, Yoga, alternative physical and psychological therapies which invoke a non-material spirituality but do not possess a theology or an ethos for society, let alone institutional arrangements for their representation or doctrinal legitimation - adding up to a 'newstyle' religion as Linda Woodhead calls it, though one may doubt whether they truly qualify for the term. ${ }^{2}$

As a result of these reflections, the article challenges a fundamental but unarticulated assumption of market theorists and others, namely that the more and the more intensely religion is practiced, and the more open the religious field, the greater the benefits for society as a whole. Following Ernest Gellner and Chris Hann, I provide a less dismissive account of the regime of religious recognition and attenuated monopoly which emerged in Western Europe, in which certain churches existed for 
nations as a whole, and thus functioned as open institutions, and a more sceptical account of the absolutism of religious freedom policies. Of course, I recognize that these national, or hegemonic, churches are not always open to everyone and that their hegemony is, to varying degrees, at the expense of minority religions and sometimes minority ethnic groups.

While the point of departure is Europe, the US and Brazil are adduced for comparison and conceptual clarification: the US case shows that a radical negation of state regulation of religion has led to endless uncertainty and litigation over what counts as religious, and maybe sharpened and embittered political conflict. Its legal and political framework shifts in accordance with the changing balance of political forces. Nowhere do the problems of delimitation arising from 'religion as belief' and 'conversion-led movements' appear as sharply as in the US. In Brazil, in contrast, which is heir to a long tradition of religious quasi-monopoly so decried by market theorists, a veritable revolution, quantitative and qualitative, in the religious practices

of the population - admittedly, and significantly, without much immigration or cultural transplantation such as has occurred in Europe - has occurred with few tensions in the political arena and (thus far) with nothing like the 'culture wars' observed in the US, even though since the 1988 Constitution the regulatory regime is similar to the US.

In conclusion, I claim that contemporary tensions around religion arise because of (a) a shift in the nature of religious claims from heritage-based to a basis in personal belief; (b) the influence of conversion-led movements and the non-availability of impersonal or impartial criteria for the recognition and adjudication of claims for religious exemption and privilege; (c) the legacy of exemptions and privileges formerly accorded to religious institutions; and (d) the political instrumentalization of religion, though this last point awaits development elsewhere.

\section{Heritage and belief}

The legitimacy of religion's presence in a national public sphere arises, according to the ruling climate of opinion and also according to the regime of religious regulation in force in Europe, from two sources which are difficult to reconcile: on the one hand 
there are institutional arrangements for state-religion relations which have been built on the assumption that religion is intuitively recognizable due to its character as a national heritage or tradition, as a social convention rather than a set of examination questions (i.e. doctrine); but on the other hand formal provisions governing religion in the public and even the private sphere (such as circumcision, rules about kosher/hallal meat and parental prerogatives in their children's upbringing) are dictated by the secular and universalist requirement of non-discrimination and non-favouritism, and they assume that religion has an abstract character shared by many religious traditions which can be encapsulated in bureaucratic norms and definitions. This second source tries hard to distance itself from religion as heritage, but the tension persists, complicated by migration and cultural globalization whereby religious practices are detached from ancient environments, and heritage is transplanted across political and geographical frontiers.

So while European institutions continue to reflect and express the heritage of religion in Europe and while many Europeans (whether or not they consider themselves religious) more or less sub-consciously recognize and value that heritage, Europe's multicultural and multi-religious populations are transforming the practical institutional impact of those institutions, either because as migrant populations they are bringing their traditions with them or, as roaming, globalized seekers for supernatural enlightenment, they are transporting ideas about the supernatural and about life across the globe into unfamiliar contexts (Altglas 2005; Altglas 2007). There thus arises a problem of authority: should recognitions and privileges accorded over many centuries to particular religious cultures and institutions, with their hierarchies and doctrines and authorized spokesmen, be extended to all those who claim recognition as religions under expanded criteria, in circumstances where the question who or what a religious authority is and whether such an authority merits any special status or regard from the state is essentially contestable?

The weakening of religion as heritage and the concomitant proliferation of religious authorities is likely to continue ever faster if the recent decision of a German Court on circumcision (in Cologne, June 27th 2012) is to be read as a sign of things to come. Apart from the inevitable outcry about its implications for the practice of age-old traditions - Jewish, Muslim and other - which were subsequently rectified by 
legislation on December 12th 2012, the ruling focused on the rights of parents to transmit their religious affiliation to their children. In the view of the court, the 'permanent and irreparable' change wrought by circumcision 'runs counter to the interests of the child, who can decide his religious affiliation himself later in life'. If this principle is upheld and extended, then the entire basis of Europe's religious regime is threatened, because all family religious rituals can be regarded as preempting the child's religious affiliation. The instance is also curious because whereas religion is usually regarded as enjoying very special exemptions and privileges with respect to the law, here it is being singled out as the one type of affiliation which parents should not impose on their children, whereas the 'imposition', for example, of language, ethnic identity, or diet, is presumably permissible.

The consequences of individual-based and therefore almost arbitrary criteria of religious belonging which operate in the United States, are vividly described by Winnifred Fallers Sullivan's documentation of a week in the life of a Florida court, observing a case in which certain citizens in Boca Raton, Florida, argued that by not allowing them to embellish their loved ones' tombstones in a municipal cemetery as they wished, the municipality was violating their religious rights (Sullivan 2005). Her account shows that the provisions of the First Amendment (non-establishment and free exercise) have been far from enough to keep religion and government from arguing ad infinitum. Rather, we observe an open-ended (but often ill-tempered) negotiation between commonsense versions of religion and judicial attempts to resolve formally thorny and often trivial disputes. Put another way, zealous individuals, sometimes backed by organized campaigns (though not in the Boca Raton case), invest in the judicial process to make their point. But note that in Latin America, where all states proclaim their 'laïc' (or 'laico') character, but where the litigation culture is different, such disputes are largely unknown in the legal sphere. The idea, though, that any contemporary regime of religious regulation has drawn crystal-clear lines around the religious sphere is highly questionable.

\section{Drawing lines and blurring them}

In France the delineation of religious and secular spheres under the regime of laïcité is the outcome of a series of milestones each of which further thickened the frontier: the 
'Loi Ferry' of 1882 which established the 'free, secular and compulsory' principle of schooling, the law of 1904 which removed clergy from the ranks of teachers in state schools, and finally the Law of 1905 on the separation of Church and State. Under this law the state ceased forever, in laïcité's classic constitutional formula, to 'recognize, pay the salaries of, or remunderate any religious institution. ${ }^{3}$ At the same time the national state became the owner of then-existing cathedrals, and the local authorities, the communes, took nominal ownership of then-existing parish churches, thus accepting responsibility for their upkeep. Yet in recent years communes, using spurious technical arguments, have been notoriously resistant to the construction of mosques, forcing Muslim worship into garages and similar precarious locations. So while they have a responsibility for the upkeep of myriads of parish churches they are able to tacitly discriminate against Muslims wanting to build places of worship, thus in effect violating the principle of non-recognition, ${ }^{4}$ and ignoring the technically abstract character of religion in a secular arrangement. ${ }^{5}$ The French state also subsidizes écoles sous contrat of which $95 \%$ were nominally Catholic in the early 1990s, but with little clerical involvement in the life of the school (Héran, 1996). However, Jewish écoles sous contrat operate such a strictly Jewish regime that the inclusion of non-Jewish students is barely imaginable, so the state is in effect subsidizing a parochial education. ${ }^{6}$ For example, a 2009 newspaper report on a girls' school in Paris run by the Lubavich sect certainly cast doubt on the idea that the state does not subsidize any religion ('L'enseignement confessionnel fait école' Libération, 28 December 2009). Even so, there are fierce disagreements among Jewish currents of opinion and practice about whether the conditionalities attached to the contract are acceptable (Birnbaum 1995: 207).

A further deviation from the image of unflinching separation is the case of the region of Alsace-Moselle where, in recognition of the region's special history as part of Germany between the Franco-Prussian War and the First World War, and the patriotism of its population, the Catholic Church enjoys official recognition and the state pays the salaries of some pastors, priests and rabbis (but not of course mullahs or imams). Alsace also had at the time a significant Jewish population, among whom the French state found numerous loyal judges and civil and military servants, not least Captain Alfred Dreyfus. ${ }^{7}$ 
In 2004, after years of periodic trivial but over-dramatized incidents, laïcité received further legislative attention in the form of a law passed by 494 vs. 36 votes in the French National Assembly, and known as the 'headscarf ban', though it is not exactly a ban and does not apply only to headscarves. The law forbids the wearing of egregious religious ornaments ${ }^{8}$ in state schools. The passage of the law was hard to interpret as anything but an expression of negative sentiments by the political elite against the country's Muslim population, and the practical effects have been quite limited: conflicts over headscarves have been rare in French schools and in accordance with a ruling by the Conseil d'Etat (Constitutional Court), have been settled locally without recourse to legal procedures, implying either that, political considerations apart, a law was an unnecessary diversion, or that it has had a powerful pre-emptive dissuasive effect. In theory the law also prohibited the wearing of the kippa by Jewish students, but the enforcement of that implication has hardly been mentioned, while representatives of the Sikhs whose turban was also caught up in the storm, have taken several cases to the European Court of Human Rights. The Conseil d'Etat tip-toed around the issue, hesitating between the view that outward religious ornaments were only to be prohibited if they undermined discipline (they used the French word 'troubles') in the classroom, and another view that pupils should avoid any 'marque ostentatoire' - any 'egregious' symbol of their religious adherence. Both cases reveal a search for what might be called a 'soft' reinterpretation of the law (Birnbaum, 1995: 205, 209-10). In May 2010 the Chamber of Deputies voted unanimously for another law, this time prohibiting the 'voile intégral' or 'full-face veil' (burqa or niqab) in public spaces. ${ }^{9}$

In a separate controversy surrounding the state's circumscribing of religion, an earlier panic-driven initiative, the 2001 loi anti-sectes, directed against Scientology and other cults, of remains a mere gesture which has been severely criticized by lawyers because, it raises issues of freedom of religion and speech, while adding nothing to existing provisions against kidnapping, brainwashing and the like, (Volff, 2005:113). In any case, that law has not given rise to effective legal action against the cults which sectors of opinion had branded abusers and practitioners of brainwashing (Altglas, 2010). ${ }^{10}$ Yet the forces of religion, or at least of the Catholic Church, are by no means powerless: only 20 years earlier President Mitterrand had been forced, by demonstrations of hundreds of thousands in support of private (overwhelmingly 
Catholic) education, to withdraw a proposed law to integrate in a fairly loose manner the public and private education systems. A similar attempt to stop legalization of gay marriage in 2013 has not been so successful.

In England (not Scotland or Wales, let alone Northern Ireland), in at least apparent contrast to France, the state-religion relationship has evolved in a less clear-cut way through a myriad of concessions and negotiations, to the point where although there is a quaintly described 'established' - i.e. official - church, and although 26 Anglican Archbishops and Bishops sit as of right in the House of Lords, and the state funds innumerable Church of England, and Catholic schools, plus a few Jewish and a tiny number of Muslim ones ${ }^{11}$, constitutional practice is highly secularized, with zero government funding of religious buildings, worship or personnel - in contrast to the prevailing arrangements in many Northern European countries, France and some Swiss cantons. In theory the English arrangements operate so as to prevent charities and schools from promoting or excluding one or another faith, although in statefunded Jewish schools the pupils are mostly Jewish, and like in France pupils and schools have become steadily more Orthodox in recent decades. Church of England and Catholic schools often attract children from religiously unaffiliated families and in predominantly Muslim neighbourhoods sometimes have a majority of Muslim children. Yet this is the same state in whose province of Northern Ireland there are institutionalized separations between Catholic/Nationalist and Protestant/Unionist electorates, whose neighbourhoods do not share social services and whose children overwhelmingly attend separate schools.

In an admittedly polemical book by Marci Hamilton which documents innumerable cases of religious prerogatives granted by the Federal and especially state governments in the US notably on taxation issues, in apparent contravention of the fourteenth amendment to the Constitution (Hamilton, 2005). The higher courts continue to duck and weave around these issues so as to avoid creating precedents on anything too religiously controversial. Both journalistic and academic accounts note that the law has fluctuated on these subjects, reflecting political pressures, and that the 1970s marked a high point in judicial assertion of separation: since then, they tell us, the claims of religious organizations have been well received by politicians concerned 
with the vote and also by the courts. Inherited legislation was presumably based on an assumption that services provided by institutions such as the Holy Cross Brothers would cater to the poor and destitute, but that is not necessarily the case any more, nor can the courts take account of such social impacts in deciding on their religious character. $^{12}$

Judges in the US also seem unwilling to clearly delineate persons whose ministry constitutes 'a core expression of religious belief' and who therefore are entitled to tax exemptions, for this might involve distinguishing between a priest and, say, a nurse employed by a religiously sponsored or managed institution. And one can understand why: is it for the courts to decide how such core roles could be distinguished? Could they seriously require some sort of criterion like a ritual of induction? Once the underlying inherited assumptions - consensual or not, but assumed to be such - about religious belonging and belief have been relativized, once they are no longer taken as self-evident and made subject to legal-rational inspection, the issue becomes not just uncertain and contentious, but also politicized, because of the competitiveness and ambition of religious organizations and entrepreneurs and the political constituencies they can influence. So as the state, in the person of judges, recoils from defining what counts as religious, on the grounds that to do so would be to violate the fourteenth amendment provision of free exercise and non-establishment, religious groups find more and more exemptions and protections within the state.

\section{Ancient understandings become arms in new struggles}

This politicization is not a matter of ideological and policy-related pronouncements by religious organizations, which are a standard feature of any remotely democratic state-religion regime. Rather it is about the destabilization of ancient implicit European understandings originating in a set of largely forgotten cultural assumptions, which retain their legitimacy in the name of new ways of being religious and of being a religion. The new ways are firstly a shift in the shared understanding of what counts as legitimate religious authority: the idea that religious authority lies with professionals in a hierarchy committed, for example, to celibacy, the renunciation of worldly possessions, the wearing of distinctive dress, or a devotion to a life of learning, sacrifice, and charity, and secondly, following from this shift away from hierarchical authority, the mobilization of personal belief as sufficient authority to 
claim the same state recognition and the same exemptions once accorded to recognized and recognizable church hierarchies. This gives rise to frequent disputes.

For example, the ideals of free exercise and non-establishment were developed in a world in which birth, marriage and death were a matter for religious authorities and the state had no involvement in people's reproductive behaviour, or in medical treatment in extreme old age, not to speak of the certification of same-sex marriages. Such issues have fuelled demands for special recognition of the religious for example from officials refusing to certify same-sex marriages or pressures for the state to fund religious schools operating a regime of strict observance. These concessions could almost amount to a separate category of citizenship under which religious affiliation exempts individuals and organizations from universal rules which in most democratic regimes are supposed to apply irrespective of 'race, religion or creed': as these demands are met so religion becomes a benefit or entitlement for followers, rather than a burden or sacrifice by people (monks, pastors etc.) whom society as a whole should subsidize, and difficult questions arise as to whether respect for religious freedom and for its benefits to society take precedence over other policies, for example to protect children's rights, or to protect parents' rights (as in anti-cult controversies). Thus we have to find a line not only between the state and religion, but also between freedom of expression and religious privilege, so that we can explain and justify why religious freedom requires privileged treatment additional to freedom of expression. This search is compounded by polarized factions and tendencies within religious groups, making it difficult for states to find legitimate negotiating partners ('interlocuteurs valables').

These conflicts could be described as the less visible, even dark, side of the 'vicarious religion', which Grace Davie sees as a salient feature of contemporary European societies. Davie describes a type of free riding where religion is 'performed by an active minority but on behalf of a much larger number who (implicitly at least) not only understand, but, quite clearly, approve of what the minority is doing' (Davie 2006: 22). (This is not the same as the relationship between the faithful and the worldrenouncing virtuosi described below and drawn from Danièle Hervieu-Léger, for that is a quasi-magical relationship binding followers to a church, not the same as a bland recognition of the value of religion in general.) Davie states that her idea is based on the religious 'middle ground' of broad but passive support for mainstream religions 
like the Church of England or the established state-funded churches of Northern Europe and Scandinavia, and my notion of religion as heritage is much the same as hers. The present analysis then complements her idea by shifting the focus away from people's feelings and beliefs to the institutional and political implications of this state of affairs, deploying 'belief' in the context of claims-making or the justification of religion, not with reference to what individuals might 'actually' believe or feel. Its argument is that with vicarious religion comes a corollary - the destabilizing force of some versions of evangelical and charismatic Christianity, of fundamentalisms of various kinds, of the transplantation of religious habits by immigration and by the search for supernatural inspiration or alleviation, and so on, with serious implications for regimes of religious regulation.

\section{Religion as an inclusive or exclusive good?}

The discussion also has to go beyond the questions of religious freedom and exemption, to ask whether religious organizations which practice exclusiveness and have no visible or answerable authority beyond a local manager (i.e. pastor) can claim the same exemptions as those which are more institutionalized. It is worth reminding ourselves that those forms of Christian religion which benefit from state bias embody a religiosity open to more or less everyone, provide parish churches serving every square kilometre of a given national territory, and are neither demanding nor exclusive, and hence fit well with vicarious religion. This contrasts with today's most rapidly growing Christian tendency, the evangelical churches, which in principle require their followers to pay a regular tithe of one tenth their pre-tax income. Sometimes openness is reflected in formal arrangements: for example, in England the established Church, and in Wales the disestablished Church, are obliged, subject to minor exceptions, to marry anyone who asks to be married by a priest - a centuriesold provision which has recently come under the spotlight because of the UK coalition government's announced intention to legislate for same-sex marriages. But the openness which matters is in the domain of symbols and public rituals: churches open to all comers, located in salient places as symbols of a city's standing or pride, or a village's shared sense of belonging, providing priests as community mediators, 
bishops to crown kings, and chaplains to minister to students, prisoners and soldiers, often as counsellors yet deriving their trust from their religious-pastoral office.

No wonder then that Ernest Gellner, who described himself variously as an atheist and an 'Enlightenment fundamentalist', argued in favour of what he called 'Constitutional Religion', on an analogy with constitutional monarchy: 'part of a cultural Broad Church' which embraces the 'legitimation of social arrangements' like religious marriage as well as non-religious activities like 'serious cognition' (i.e. scientific rationality), allowing individuals to 'locate themselves at will' along that spectrum (Gellner, 1992: 91-92). In the same vein, Chris Hann (2000) raises a serious question whether one can justify untrammelled opening up of religious regulation without regard for the institutionalization and accountability of the organizations thus benefited. Questioning the benefits to civility brought by opening up the religious field in Eastern Europe's postsocialist countries, Hann argues that 'the retention of a "lukewarm" faith offers the best chances for tolerance and freedom. In several of these countries the religious field has been opened to competition in response to 'international religious human rights-ism' promoted by 'well-funded transnational pressure groups' which have built alliances with the most conservative elements in the national churches (Hann, 2000; Hann, 2006), leading to bitter controversies over women's reproductive rights, predictably, but also little enhancement of freedom accompanied by tacit acquiescence in attitudes to Jews and actions against Gypsies, which, to say the least, inspire a legitimate fear for their freedom and even their safety, and hardly enhance human rights.

Hann is here making a discrete argument against the rapid adoption of secularism or of an unrestricted 'religious market' in countries where the field was previously dominated by a national church or 'confessionalist' regime (Koenig, forthcoming) because the sudden shift can tear apart the social fabric. The point about politicization can also be formulated in terms of Daniéle Hervieu-Léger's emphasis on the openness and inclusiveness of a Church which, being charged with the redemption of all mankind, distinguished between the strict observance and personal sacrifice required of its virtuosi, and the minimal observance asked of its followers (Hervieu-Léger, 2001: 141), in contrast to conversion-led movements which demand heavy sacrifice from all followers. Sects, unlike national churches, are distinguished by their inwardlooking focus and the intense personal commitment required of their members. But 
one can go further, and ask whether the absence of even a nominally national Church is not a factor behind the political involvement of churches in the US, which in recent history has ranged from the civil rights movement to the Tea Party and the current culture wars, described by Putnam and Campbell (2010) as the bitterest ideological battles that country has ever seen.

It was not always so divisive, for churches have been a central element in civic life in American townships ever since Tocqueville, as can be seen from Robert Wuthnow's recent religious history of Kansas (Wuthnow 2012), which describes in engrossing detail the centrality of churches in the civic life of small towns. But more recently religious leadership, which until Prohibition in rural Kansas tended to be a force for political consensus, has tended to encourage polarization at national and local level (culminating in Kansas in the murder, in the doorway of his church in May 2009, of a doctor who ran an abortion clinic).

The polarization appears to be related to the openness of the religious market and invites two observations. One is that where there is a history of hegemony or establishment there are fairly stable institutional arrangements for the management of the interaction between the state and religious bodies, such as the French schooling arrangements we have mentioned (absent in the US). These arrangements may not be strictly compliant with a demanding interpretation of separation, and they are also very likely to be biased against minority religions, but in the European countries where they prevail there has hitherto, in the $20^{\text {th }}$ century, been a degree of tolerance for that, and a (still) limited pressure for judicial intervention in drawing detailed definitions and frontiers - an ultimately impossible task for judicial reasoning, as the contrasting interpretations of the ECHR by Edmunds and Koenig illustrate (Edmunds, 2012; Koenig, forthcoming). The second is that where there are elaborate and longstanding institutional arrangements for a Church both to govern itself and to deal with the state there may be less tension over religious exemptions and prerogatives, and, despite establishment as in England, the state may in fact be more laïc $^{13}$ than in the US because there are established consensus-based mechanisms to prevent unwarranted interference, and areas of competence are clearly demarcated. Note again that the issue is not the intervention of religious leaders and organizations in public political debate or their influence on the electorate, but rather the stability and 
legitimacy of a consensus about the rules and traditions governing the interaction between religious and state institutions. Even so, the arrangements are eroded by new understandings of religion already mentioned, and by internal divisions within religious communities over the proper role of the state.

In that respect this argument diverges from the (implicit but rarely enunciated) assumption underlying the economics of religion school, in the writings of Rodney Stark and his associates, that the less regulated a regime of state-religion relations the better not only for religious organizations but also for society as a whole. In this perspective, religion need only justify its benefit to its own followers, not to society as a whole, so that the inclusiveness of a church is not a value (Iannaccone, 1994; Iannacone, 1997; Stark, 1997; Stark and Finke, 2000; Lehmann, 2010). The implication also is that, pace Grace Davie's earlier account of Europe (2002), one way or another all countries are exceptions, but the US is an outlier, an exception among exceptions which diverges more from all the others than any other in Europe or the Americas.

A good illustration is provided by the Church of England, bearer of a national and open religious tradition, which now, in a time of declining Christian religious observance, and proliferating religious affiliations, all seeking recognition, finds itself in the role of guardian of the idea and legitimacy of religion in general - any religion. The liberal voice, even if it is drowned out occasionally by an 'evangelical wing', goes beyond managing the vicarious enjoyments of a Christian religion, and finds itself entrusted with managing multi-faith coexistence, being considered implicitly and institutionally as 'above the fray'. In the fascinating and sometimes amusing description of religious provision in English prisons by Beckford and Gilliatt (1998), for example, Church of England officiants tried to 'create opportunities for sharing "common ground" between prisoners of different faith traditions', and tended to promote 'religion in general', leading to some almost surreal situations. And their ethnography is nicely complemented by a lecture given by the former Archbishop of Canterbury, Rowan Williams, in 2008, when, à propos of Sharia law, he defended the recognition by the state of 'structures or protocols that embody the diversity of moral reason in a plural society by allowing scope for a minority group to administer its affairs according to its own convictions' (Williams, 2008: 268). Of course the lecture was lambasted in the tabloid press, as advocacy of the introduction of Sharia, whereas 
his true purpose was to insist on the need for secular arrangements precsely to protect people within minority communities from the violation of their universal rights, by bringing Sharia under the protective umbrella of the legal system (Williams, 2008: 271-2). The Archbishop, like the prison chaplains, was giving voice to a liberal secularist, but obviously far from atheistic, mindset: religion at the service of society and the world (which is not reducible to charitable giving).

\section{Conversion-led movements and the secularization of religious reason}

The dynamic forces in religion as option or preference are conversion-led movements. I use this term so as to encompass all sorts of movements in Christianity, Judaism and Islam which are commonly labelled fundamentalist, charismatic or evangelical, but have this one factor in common: their followers describe their adherence in terms of a life-changing conversion experience. The notion of 'conversion-led' overcomes the difference between traditions and offers a more analytical or generic description of them as a social phenomenon, avoiding a theological characterization while encompassing both charismatics and certain types of fundamentalist. The success of these movements challenges the idea of religion as heritage, as 'imbibed with mother's milk' and reinforces that of religion as an option or life choice, so they do not depart radically from vicarious religion Among Muslims and Jews it takes the form, generally, of religious renewal, return or reversion - in short a 'return' (as Jews call it) to strict observance by people who have been brought up with little or no religious observance. (Metcalf, 1996; Lehmann and Siebzehner, 2006). Among Christians, millions have adopted Pentecostalism (Martin, 2001; Maxwell, 2006; Corten and Marshall-Fratani, 2001; Freston, 2001 and many others) having previously been inactive Catholics or Protestants, or irreligious, or involved in possession cults of various kinds, so that, according to census figures, today $22.2 \%$ of almost 200 million Brazilians belong to evangelical churches, up from $15.4 \%$ in 2000. (The figure, however, includes $4 \%$ in what Americans call 'mainline' and Brazilians call 'historic' Protestant churches, and $4.8 \%$ 'indeterminate evangelicals' so the $22.2 \%$ is an exaggeration. ${ }^{14}$ ) It must be emphasised that although the Universal Church of the Kingdom of God and other neo-Pentecostal churches like them grab the headlines, the Assemblies of God which broadly speaking represent 'classic' Pentecostalism, still constitute the overwhelming majority, The religious ethos of these movements tends 
to be inward-looking and this-worldly, encouraging followers to focus on personal discipline and on contributions in time and money to the movement with little attention to the transcendental, to theology or to religion's contribution to society. Classic Pentecostalism may be austere and humble storefront chapels may be its trade mark, but it does not invoke the transcendental in the sense in which, for example, Charles Taylor understands the word. While Taylor's emphasis is on 'the sense that there is some good higher than, beyond human flourishing' (Taylor 2007: 20), Pentecostalism, and especially neo-Pentecostalism, focuses precisely on human flourishing, success and wellbeing, and on a supernatural which is not at all the same as Taylor's higher good. Their supernatural, especially among neo-Pentecostals, is either a possessive force outside the self which prevents or even poisons the realization of an individual's potential, or the help of Jesus in achieving that human flourishing and personal empowerment, by a leap of self-belief. Of course, ideas about other-worldly salvation are recognized, but receive little mention.

Neo-Pentecostalism has taken up the themes of conversion and healing and speaking in tongues and combined it with a cult of the spectacular and of worldly success, and with a choreography of life as a drama in which the individual faces constant threats from the forces of evil (Birman 2007). The model developed by the neo-Pentecostal Universal Church of the Kingdom of God, founded in Brazil in 1979, has spawned many imitators in Brazil and in Africa, with extensions in Europe, and seems to be the most dynamic such force in world Pentecostalism, characterized by large-scale centralized churches with a global, multinational reach. Neo-Pentecostal churches make insistent demands for donations during religious services, and proclaim the promise of worldly success, often as embodied in the prosperity exhibited by their leaders (Lehmann 1996; Comaroff, 2009; Marshall, 2009). Neo-Pentecostal preaching consists of summary morale-boosting exhortations, accompanied by exemplary reallife histories of triumph over adversity and material success (Campos, 1997). Heaven and indeed hell are here on earth, and the Churches offer a cure for the afflictions of the world more than a refuge from them. The task of the Church is not primarily to heal the world but to empower individuals. Procedures and symbols are adopted and abandoned with little regard for a 'system' or 'tradition' and artefacts and symbols are borrowed and then culled like seasonal decorations, as illustrated by the adoption of Jewish or quasi-Jewish paraphernalia by the Universal Church and others. It is an 
untrammelled type of religious enterprise which recognizes few external constraints on the claims it can make in the name of religion and grates against European traditions of religious regulation. The model pioneered by this organization has made it into a vast global operation and has also been successfully adopted by many others.

\section{Political involvement of conversion-led movements}

On the whole, Pentecostals in Latin America have not posed serious problems for regimes of religious regulation: their involvement in politics is largely of a corporatist kind, seeking office and resources, and they do not adopt the kind of politicalreligious rhetoric that is heard in the United States, whether on the left, as in the civil rights movement, or associated with fundamentalist Christianity and linked to issues such as civil rights, social policy, taxation and government expenditure (Fonseca, 2008; Freston, 2008; Gomes 2011; Machado, 2006). Classic Pentecostals are as hostile to abortion and same-sex marriage as the Catholic hierarchy, but in Brazil the Universal Church's leader has taken a mainstream liberal position on the subject (Duarte et al., 2009: 54). The Brazilian Congress has an evangelical caucus of about 63 Deputies and 3 Senators and two political parties. This involvement in politics is not an issue for laicidad(e), because they do not demand the sorts of prerogatives which the Catholic Church has had in the past in some Latin countries. Several court cases against Pentecostal and neo-Pentecostal churches in Brazil have concerned misappropriation of church funds (see for example Isto E, 9 September 2011) and harassment of Afro-Brazilian religions and slandering of their officiants - whom the Universal Church has on one occasion been obliged to compensate. No important case has concerned their status as religious organizations. Since the 1990s religious associations are recognized separately from associations in general, which exempts them from tax but not from the obligation to supply tax returns (Giumbelli, 2008), something from which the Catholic Church is exempt under a 2008 Concordat. This results in something of a free-for-all in which the title of 'religion' is hard to withhold from any organization. It is therefore disquieting that the selfsame Universal Church is said to use its followers' contributions to subsidize TV Record, owned by its leader Edir Macedo, by overpaying for air time occupied by night-long religious programmes. Recently the issue was highlighted by the Folha de São Paulo (February 20, 2013): à propos of a surge in church income, which has now reached the equivalent of US $\$ 10$ billion in one year ${ }^{15}$, the newspaper said the state has no way of 
dealing with 'business-religions' whose leaders own private jets, mansions, publishing houses and TV networks. ${ }^{16}$ On the other hand, there are also indications that the tax authorities are keeping up or that the Universal Church does take care to keep its affairs in order: a current (2013) court case concerning the taxing of the millions of dollars' worth of stone it has imported from Israel to build the façade of its monumental 'Temple of Solomon' in São Paulo revolves around the issue of whether the stone is essential to the Church's religious functioning and exempt on those grounds. ${ }^{17}$

Conversely, there has been little if any human-rights-based litigation in Brazil such as we have seen in Europe around religious discrimination, school uniforms, headscarves or the like: most Latin American countries, seem to live peaceably with a fuzzy arrangement in which the law is not brought into such issues. In Brazil, specifically, there is also the additional meaning of heritage because the possession cults are a shared national heritage, another open religion in the terms enunciated above, to which many Brazilians, usually at least nominal Catholics, can have recourse when they feel the need. Even the cult of Santo-Daime, whose adepts regularly take the dangerous drug ayahuasca, are exempt from repressive measures, presumably because of their popularly recognized religious status. So on the one hand there are few barriers to religious status, but on the other hand there are few exemptions and privileges except for the major issue of tax, and, so far, there is little mobilization of religion in the name of non-religious issues.

But this sanguine evaluation of the state of play in Brazil may underestimate changes in the relationship between religion and the state. The polemics over same-sex marriage and abortion, have recently become very shrill and even bitter: in March 2013 there was uproar against the appointment of Marco Feliciano, a Pentecostal pastor and vociferous opponent of homosexuality, as President of the Congressional Human Rights Commission. But he defended himself uncompromisingly, and such moments may herald a new turn in these matters. Having been appointed as part of an intricate inter-party division of such posts, Feliciano remained.

\section{Conclusion}


If, in this three way comparison, the true outlier is the United States, this is because it has no history of a national or hegemonic church, which all European and Latin American countries do have, and because in the twentieth century religion has played such a prominent role in social conflicts in that country, and today plays a uniquely prominent and polarizing role in its politics. The implication is that there is no single model of a secular order, and there are many models of state-religion relations. To encompass them what is needed is a concept of secularism as a regime of statereligion relations. regime being defined as 'a set of 'implicit or explicit principles, norms, rules, and decision-making procedures around which actors' expectations converge in a given area' (Krasner, 1982: 185) - and in which impersonally adjudicated rules govern the relations between state ands religion.

But while the regimes vary so much, the conversion-led movements, as products or at least correlates of globalization, have numerous features in common across the world. They are by no means majority movements, but their impact has been far out of proportion to their numbers because within the religious field they are much more dynamic, and their followers more committed than other tendencies which conceive religious adherence differently. Indeed, one central argument is that regimes of statereligion relations have great difficulty dealing with religious movements and subcultures which demand high levels of commitment from their followers, because their institutions - whatever their origin - have been adapted to deal with low-intensity religion in which clergy do the hard work and the followers follow. Liberal secularists must now take these phenomena seriously and develop ways of including them, just as the Archbishop wanted to include Sharia, rather than dismissing them as mad, irrational or ignorant.

Notes

1. The Pew Forum on Religion in Public Life published survey results in October 2012 showing a slow but steady growth of the 'religiously unaffiliated' in the US from $15.3 \%$ in 2007 to $19.6 \%$ in 2012 . The distribution was heavily skewed by age, and the report was careful to note nevertheless that $68 \%$ of the religiously unaffiliated 'believe in God'. www.pewforum.org

2. 'See her lecture at the conference on new Forms of Public Religion at St John's College, Cambridge, September 2012, and her unpublished paper 'Strategic and Tactical Religion (May 2012). 
3. 'La République ne reconnaît, ne salarie ni ne subventionne aucun culte.'

4. This is what might be called 'negative recognition'.

5. The Swiss are more straightforward. After a referendum in 2009 their Constitution now contains the phrase: 'La construction de minarets est interdite.'

6. As is the case in England for the strictly Orthodox 'Beit Yakov' girls' schools in London and Manchester, where a similar arrangement allows the state to pay for the secular curriculum but not religious learning.

7. Hence the classic phrase 'les juifs fous de la République' - 'Jews madly in love with the Republic'.

8. The exact text prohibits the following: 'le port de signes ou tenues par lesquels les élèves manifestent ostensiblement une appartenance religieuse'.

9. The penalty is symbolic: $€ 150$ or a citizenship course. The penalty for inciting someone to wear it is much heavier: $€ 30,000$. The number of women wearing a burqa at the time was derisory, but of course has risen since.

10. The intimidatingly named MIVILUDES (Mission interministérielle de vigilance et de lutte contre les dérives sectaires) the non-statutory body established in the wake of the law to monitor and fight against the spread of sectarian patterns of behaviour, makes a point on the opening page of its website, of stating that its task is not to define a sect nor to keep a list of sects, but rather to keep abreast of the 'dérives sectaires'. The list of these patterns makes it clear that what in French is called 'sectes' would be best rendered in English by 'cult'. http://www.miviludes.gouv.fr/missions/principes-daction

11. The Church of England website states that there are 4,800 CofE state-funded schools, and the Catholic Education Service says it has 2,000. Numbers are not easily available for state-funded Jewish or Muslim schools.

12. On October 6,7 and 82008 the New York Times ran a series of articles under the title 'In God's Name' documenting extensive tax breaks, immunity from employment legislation, immunity from safety legislation and the like for not just places of worship but for all sorts of businesses and facilities run by religious communities like day-care centers, retirement homes, and universities.

13. I use laïc in the place of 'secular' because it refers specifically to the lines of demarcation and the institutions which exist to manage those lines.

14. The terms in Portuguese are 'evangélicos', divided into those 'de origem Pentecostal', 'evangelicos de missão' and 'evangélicos não determinados'. The use of the term 'de missão' derives from the identification of historic Protestant churches with immigrant groups from Europe in the late $19^{\text {th }}$ and $20^{\text {th }}$ centuries, who received or brought missionary families with them.

15. This information is available because although they are tax exempt, churches and other religious bodies (except the Catholic Church) must present accounts to the tax authorities. No doubt vast amounts remain undeclared, especially of cash donations.

16. The leader of the Universal Church of the Kingdom of God, for example, is said by Forbes to be worth almost one billion dollars, and among the next five wealthiest pastors are two former associates of his whose worth is in the hundreds of millions. See www.forbes.com 17 January 2013.

17. See 'As pedras no caminho da Universal', Veja (São Paulo), 13 March 2013. and http://www.otemplodesalomao.com 


\section{References}

Altglas V (2005) Le nouvel hindouisme occidental. Paris, CNRS Editions.

Altglas V (2007) The Global Diffusion and Westernization of Neo-Hindu Movements: Siddha Yoga and Sivananda Centres. Religion in South Asia 1(2): 217-237.

Altglas V (2010) Laïcité is what laïcité does: rethinking the French cult controversy, Current Sociology 58(3): 489-510.

Asad T (1993) Genealogies of religion: discipline and reasons of power in Christianity and Islam. Baltimore: Johns Hopkins University Press.

Beckford J and Gilliat S (1998) Religion in Prisons: equal rites in a multi-faith society. Cambridge: CUP.

Birman P (1998) Feminine mediation and Pentecostal identities. Cambridge Anthropology 20(3): 66-83.

Birman P. (2007) Conversion from Afro-Brazilian religions to neo-Pentecostalism: opening new horizons of the possible. In E. Cleary and T. Steigenga (eds) Conversion of a continent: contemporary religious change in Latin America. New Brunswick: Rutgers University Press.

Birnbaum, $\mathrm{P}$ (1995) Destins juifs: de la Révolution Française à Carpentras. Paris: Calmann-Lévy.

Comaroff J (2009) The Politics of Conviction: Faith on the Neo-liberal Frontier. Social Analysis 53(1): 17-38.

Corten, A. and Marshall-Fratani R (eds) (2001). Between Babel and Pentecost: transnational Pentecostalism in Africa and Latin America. London: Hurst \& Company.

Davie G (2002) Europe: the exceptional case: parameters of faith in the modern world. London: Dartington, Longman and Todd.

Davie, G. (2006). Vicarious Religion: a methodological challenge. In Nancy T. Ammerman (ed)Everyday Religion: Observing Modern Religious Lives. New York, OUP

Duarte LFD,. de Campos Gomes E, Menezes R and Natividade M (eds.) (2009) Valores Religiosos e Legislação No Brasil: Projetos de Lei Sobre Temas Morais Controversos. Rio de Janeiro: Garamond.

Edmunds J (2012) The limits of post-national citizenship: European Muslims, human rights and the hijab. Ethnic and Racial Studies 35(7): 1181-1199.

Fonseca AB (2008) Religion and democracy in Brazil: a study of the leading evangelical politicians. in P. Freston (ed) Evangelical Christianity and democracy in Latin America. New York: OUP. 
Freston P (2001) Evangelicals and politics in Africa, Asia, and Latin America. Cambridge: Cambridge University Press.

Freston P (ed) (2008) Evangelicals and democracy in Latin America. New York: Oxford University Press.

de Campos Gomes E(2011) A Era das Catedrais: a autenticidade em exibição. Rio de Janeiro: Garamond.

Gay y Blasco P (2002) Gypsy/Roma diasporas: a comparative perspective." Social Anthropology 10(2): 173-188.

Gellner E (1992) Postmodernism, reason and religion. London: Routledge.

Giumbelli E (2008) A presença do religioso no espaço publico: modalidade no Brasil. Religião e Sociedade 28(2): 80-100.

Hamilton M (2005) God vs. the Gavel: Religion and the Rule of Law. New York: Cambridge University Press.

Hann C (2000) Problems with the (de)privatization of religion. Anthropology Today 16 (6): 14-20.

Hann C (2006). Introduction: Faith, Power and Civility after socialism. In C. Hann (ed) The postosocialist religious question: faith, power and civility after socialism. Berlin: Lit.

Heilman SC and Friedman M (2010) The Rebbe : the life and afterlife of Menachem Mendel Schneerson. Princeton: Princeton University Press.

Héran F (1996) École publique, école privée: qui peut choisir? Economie et Statistique (293): 17-39.

Hervieu-Léger D (2001) La Religion en Miettes ou: la Question des Sectes. Paris: Calmann-Lévy.

Hervieu-Léger D (2001) Religion as a chain of memory, Cambridge: Polity Press.

Hunt S and Lightly N (2001) The British black Pentecostal 'revival': identity and belief in the 'new' Nigerian churches. Ethnic and Racial Studies 24(1).

Iannaccone L R (2002). A marriage made in heaven? Economic Theory and Religious Studies. The expansion of economics: towards a more inclusive social science. ed. S.

Grossbard-Schechtman and C. Clague. Armonk, M.E. Sharpe.

Iannaccone L R (1994) Why Strict Churches Are Strong, The American Journal of Sociology 99(5): 1180-1211.

Iannacone L (1997) Introduction to the economics of religion, Journal of Economic Literature 36 (3): 1465-1495.

Koenig M (forthcoming) Human rights, judicial politics, and institutional secularization - contentions over religious diversity at the European Court of Human 
Rights. In: Kymlicka W. and Bolden J. (eds.) International Approaches to the Governance of Ethnic Diversity New York: Oxford University Press.

Krasner S (1982) Structural causes and regime consequences: regimes as intervening variables, International Organization 36 (2): 185-205

Lehmann D (1996) Struggle for the Spirit: popular culture and religious transformation in Brazil and Latin America. Oxford: Polity Press.

Lehmann D (2012) Israel: State management of religion or religious management of the state? Citizenship Studies 16(8): 1029-1043

Lehmann D. (2010) Rational Choice and its Critics. IN: B. Turner (ed) The New Blackwell Companion to the Sociology of Religion. New York: Wiley, pp. 181-200.

Lehmann D and Siebzehner B (2006) Remaking Israeli Judaism: the challenge of Shas. London: Hurst and Co.

Campos Machado M das D (2006) Política e Religião: a participação dos Evangélicos nas eleições. Rio de Janeiro: Editora FGV.

Marshall R (2009). Political Spiritualities: the Pentecostal Revolution in Nigeria Chicago, Chicago University Press.

Maxwell D (2006) African gifts of the spirit: Pentecostalism \& the rise of a Zimbabwean transnational religious movement. Oxford, James Currey.

MIVILUDES (Mission interministérielle de vigilance et de lutte contre les derives sectaires) (2006) Rapport au Premier Ministre. Paris, La Documentation Française.

Putnam R and Campbell D (2010) American Grace: how religion divides and unites us. New York: Simon and Schuster.

Stark R (1997). Bringing the theory back in. In: L Young (ed) Rational choice theory and religion: summary and assessment. London: Routledge, pp. 3-22.

Stark R and Finke R (2000) Acts of faith: explaining the human side of religion. Berkeley: University of California Press.

Sullivan WF (2005) The impossibility of religious freedom. Princeton, NJ, Princeton University Press.

Taylor C (2007) A Secular Age. Cambridge MA, Harvard University Press.

ten Haar G (1998) Strangers and sojourners: religious communities in the diaspora. Leuven: Peeters.

Volff J (2005) Le droit des cultes. Paris, Dalloz.

Williams R (2008) Civil and religious law in England._Ecclesiastical Law Journal 10(262-28). 
Wuthnow R (2012) Red State Religion: faith and politics in America's heartland. Princeton, Princeton University Press.

${ }^{1}$ The Pew Forum on Religion in Public Life published survey results in October 2012 showing a slow but steady growth of the 'religiously unaffiliated' in the US from $15.3 \%$ in 2007 to $19.6 \%$ in 2012 . The distribution was heavily skewed by age, and the report was careful to note nevertheless that $68 \%$ of the religiously unaffiliated 'believe in God'. www.pewforum.org

${ }^{2}$ See her lecture at the conference on new Forms of Public Religion at St John's College, Cambridge, September 2012, and her unpublished paper ' Strategic and Tactical Religion (May 2012).

3 'La République ne reconnaît, ne salarie ni ne subventionne aucun culte.'

${ }^{4}$ This is what might be called 'negative recognition'.

${ }^{5}$ The Swiss are more straightforward. After a referendum in 2009 their Constitution now contains the phrase: 'La construction de minarets est interdite.'

${ }^{6}$ As is the case in England for the strictly Orthodox 'Beit Yakov' girls' schools in London and Manchester, where a similar arrangement allows the state to pay for the secular curriculum but not religious learning.

${ }^{7}$ Hence the classic phrase 'les juifs fous de la République' - 'Jews madly in love with the Republic'.

${ }^{8}$ The exact text prohibits the following: 'le port de signes ou tenues par lesquels les élèves manifestent ostensiblement une appartenance religieuse'.

${ }^{9}$ The penalty is symbolic: $€ 150$ or a citizenship course. The penalty for inciting someone to wear it is much heavier: $€ 30,000$. The number of women wearing a burqa at the time was derisory, but of course has risen since.

${ }^{10}$ The intimidatingly named MIVILUDES (Mission interministérielle de vigilance et de lutte contre les dérives sectaires) the non-statutory body established in the wake of the law to monitor and fight against the spread of sectarian patterns of behaviour, makes a point on the opening page of its website, of stating that its task is not to define a sect nor to keep a list of sects, but rather to keep abreast of the 'dérives sectaires'. The list of these patterns makes it clear that what in French is called 'sectes' would be best rendered in English by 'cult'. http://www.miviludes.gouv.fr/missions/principes-daction

11 The Church of England website states that there are 4,800 CofE state-funded schools, and the Catholic Education Service says it has 2,000. Numbers are not easily available for state-funded Jewish or Muslim schools.

${ }^{12}$ On October 6,7 and 82008 the New York Times ran a series of articles under the title 'In God's Name' documenting extensive tax breaks, immunity from employment legislation, immunity from safety legislation and the like for not just places of 
worship but for all sorts of businesses and facilities run by religious communities like day-care centers, retirement homes, and universities.

${ }^{13}$ I use laïc in the place of 'secular' because it refers specifically to the lines of demarcation and the institutions which exist to manage those lines.

${ }^{14}$ The terms in Portuguese are 'evangélicos', divided into those 'de origem

Pentecostal', 'evangelicos de missão' and 'evangélicos não determinados'. The use of the term 'de missão' derives from the identification of historic Protestant churches with immigrant groups from Europe in the late $19^{\text {th }}$ and $20^{\text {th }}$ centuries, who received or brought missionary families with them.

${ }^{15}$ This information is available because although they are tax exempt, churches and other religious bodies (except the Catholic Church) must present accounts to the tax authorities. No doubt vast amounts remain undeclared, especially of cash donations. ${ }^{16}$ The leader of the Universal Church of the Kingdom of God, for example, is said by Forbes to be worth almost one billion dollars, and among the next five wealthiest pastors are two former associates of his whose worth is in the hundreds of millions. See www.forbes.com 17 January 2013.

${ }^{17}$ See 'As pedras no caminho da Universal', Veja (São Paulo), 13 March 2013. and http://www.otemplodesalomao.com 